\title{
POSSIBILITIES OF CORROSION ASSESSMENT OF METALS IN BIODIESEL USING EIS
}

\author{
POSIBILIDADES DE EVALUACIÓN DE LA CORROSIÓN DE METALES \\ EN BIODIESEL USANDO EIS
}

\author{
Jorge A. Calderón ${ }^{1 *}$, Libia M. Baena ${ }^{1}$ and Julian Lenis ${ }^{1}$ \\ 'Universidad de Antioquia, Medellín, Colombia \\ e-mail: jcaldergut@gmail.com
}

(Received: Sep. 27, 2013; Accepted: May 05, 2014)

\begin{abstract}
$\mathrm{B}$ iodiesel is an alternative fuel obtained from renewable sources. However, during the biodiesel autooxidation, reactive compounds could be formed. Those compounds increase the biodiesel corrosivity and the degradation of the fuel. This work presents a study of the corrosion of metals commonly used in auto-parts exposed to biodiesel and biodiesel-fatty acids blends. Electrochemical Impedance Spectroscopy (EIS) measurements were performed during the exposition time in order to determine the susceptibility of the metals to corrosion. The polarization resistance (Rp) values at the initial exposition times were of the order of $1 \times 10^{9} \mathrm{ohm} \cdot \mathrm{cm}^{2}$, and the associated capacitances were of the order of $10^{-11} \mathrm{~F} \cdot \mathrm{cm}^{-2}$ for all metals. The Nyquist impedance diagrams of copper and carbon steel -immersed in biodiesel-fatty acid blends after the second day of immersion- showed at least 2 capacitive loops. Although the capacitance values of lowest frequency loop are still too small $\left(10^{-9} \mathrm{~F} \cdot \mathrm{cm}^{-2}\right)$ to be associated with a metal double layer capacitance, the values of these capacitances increased with the increment of the exposition time. It is possible that for longer times of exposition, the electrochemical parameter related with the lowest capacitive loop of the impedance can be associated to the metal corrosion phenomena.
\end{abstract}

Keywords: Biodiesel, Corrosion, Electrochemical Impedance Spectroscopy.

How to cite: Calderón, J. A., Baena, L. M. \& Lenis, J. (2014). Possibilities of corrosion assessment of metals in biodiesel using EIS. CT\&F - Ciencia, Tecnología y Futuro, 5(4), 85-96.

*To whom correspondence should be addressed

+XII Congreso Nacional de Corrosión y III Internacional de Integridad 2013, Universidad Tecnológica de Pereira and Asociación Colombiana de Corrosión y Protección (ASCOR), Colombia, 8 - 10, May 2013. 


\title{
RESUMEN
}

\begin{abstract}
I biodiesel es un combustible alternativo obtenido de fuentes renovables. Sin embargo, durante la - auto-oxidación de biodiesel pueden formase compuestos reactivos. Tales compuestos incrementan L la corrosividad del biodiesel y la degradación del combustible. Este trabajo presenta un estudio de la corrosión de metales comúnmente utilizados para la fabricación de autopartes expuestos a biodiesel y a mezclas de biodiesel-ácidos grasos. Medidas de Espectroscopia de Impedancia Electroquímica (EIE) fueron realizadas durante la exposición para determinar la susceptibilidad a la corrosión de los metales. Los valores de resistencia a la polarización (Rp) al inicio de la exposición son del orden de $1 \times 10^{9} \mathrm{ohm} \cdot \mathrm{cm}^{2}$ y las capacitancias del orden de $10^{-11} \mathrm{~F} \cdot \mathrm{cm}^{-2}$ para todos los metales. Los diagramas de impedancia Nyquist del cobre y del acero al carbono, inmersos en mezclas de biodiesel-ácidos grasos después del segundo día de inmersión, presentan al menos 2 bucles capacitivos. Aunque los valores de capacitancia del bucle a baja frecuencia son aún muy pequeños $\left(10^{-9} \mathrm{~F} \cdot \mathrm{cm}^{-2}\right)$ para ser asociados con la capacitancia de doble capa, ellos aumentan con el incremento del tiempo de exposición. Es posible que para mayores tiempos de exposición los parámetros electroquímicos del bucle capacitivo a baja frecuencia puedan asociarse a fenómenos de corrosión de los metales.
\end{abstract}

Palabras clave: Biodiesel, Corrosión, Espectroscopia de impedancia electroquímica.

\section{RESUMO}

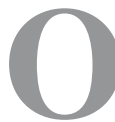

biodiesel é um combustível alternativo obtido de fontes renováveis. Porém, durante a auto-oxidação de biodiesel podem ser formados compostos reativos. Tais compostos aumentam a corrosividade do biodiesel e a degradação do combustível. Este trabalho apresenta um estudo da corrosão de metais normalmente utilizados para a fabricação de autopeças expostas ao biodiesel e às misturas de biodiesel-ácidos graxos. Medidas de Espectroscopia de Impedância Eletroquímica (EIE) foram realizadas durante a exposição para determinar a susceptibilidade à corrosão dos metais. Os valores de resistência à polarização (Rp) ao início da exposição são da ordem de $1 \times 10^{9} \mathrm{ohm} \cdot \mathrm{cm}^{2}$ e as capacitâncias da ordem de $10^{-11} \mathrm{~F} \cdot \mathrm{cm}^{-2}$ para todos os metais. Os diagramas de impedância Nyquist do cobre e do aço ao carbono, imersos em misturas de biodiesel-ácidos graxos depois do segundo dia de imersão, apresentam ao menos 2 buckles capacitivos. Ainda que os valores de capacitância do buckle a baixa frequência são ainda muito pequenos $\left(10^{-9} \mathrm{~F} \cdot \mathrm{cm}^{-2}\right)$ para serem associados com a capacitância de dupla camada, eles aumentam com o acréscimo do tempo de exposição. É possível que para maiores tempos de exposição os parâmetros eletroquímicos do buckle capacitivo a baixa frequência possam ser associados a fenômenos de corrosão dos metais.

Palavras-chave: Biodiesel, Corrosão, Espectroscopia de Impedância Eletroquímica. 


\section{INTRODUCTION}

Biodiesel -as an alternative fuel- has some technical advantages over conventional diesel fuel; however, tends to be more corrosive than diesel. The corrosive nature of biodiesel can be caused by free water and free fatty acids present in the fuel (Fazal, Haseeb \& Masjuki, 2010; Kamiński \& Kurzydłowski, 2008). Free fatty acids in biodiesel may exist as result of incomplete transesterification reactions, which are commonly found during production processes of biodiesel (Haseeb, Masjuki, Ann \& Fazal, 2010). Compared with diesel, biodiesel has a greater tendency to absorb water because the esters have hygroscopic properties, which can increase the water content in the biodiesel (Kamiński \& Kurzydłowski, 2008). Water tends to condense on the surface of the tanks, containers, pipes or metal structures in contact with the fuel, causing corrosion and deterioration of the material. During the oxidation process of biodiesel, methyl esters from fatty acids can form free radicals which rapidly react with oxygen to form volatile products such as aldehydes, ketones, lactones (Sarin et al., 2009) and organic acid compounds such as formic, acetic, propionic, oleic, linoleic myristic (Niczke, Czechowski \& Gawel, 2007). The products of auto-oxidation reactions can increase the corrosivity of biodiesel as well as increase fuel degradation (Kaul et al., 2007). Copper and its alloys are the metals most affected by biodiesel, especially when exposed to light (Aquino et al., 2012). However, depending on storage conditions, other metals may corrode when they are put in prolonged contact with the fuel (Kaul et al., 2007).

Electrochemical measurements from highly resistive electrolyte media, such as pure biodiesel or bioethanol, are difficult. Polarization techniques, for example, are not recommended because of the high ohmic drop generated when the working electrode is moved from corrosion potential. Therefore, when electrochemical polarization is required, additional electrolytes must be added in order to increase the conductivity of the fuel. These are the cases of the corrosion studies performed with carbon steel in bioethanol (Lou, Yang \& Singh, 2010) and iron in methanolic solution (Brossia, Gileadi \& Kelly, 1995). However, it has been demonstrated that the Open-Circuit Potential (OCP) of carbon steel responded to solution deaeration differently depending on whether supporting electrolyte was added (Sridhar,
Price, Buckingham \& Dante, 2006). Consequently, the addition of some chemical compounds to increase the conductivity of the fuel may not be a suitable way to evaluate corrosion of metals. An alternative tool to assess corrosion of metals in fuels is the use of microelectrodes (Gui \& Sridhar, 2010; Gui, Sridhar \& Beavers, 2010). This technique has been proposed to perform potentiodynamic polarization of carbon steel microelectodes in ethanol, without the addition of any supporting electrolyte. The corrosion rates obtained with microelectrodes are comparable with corrosion rates calculated from mass loss (Gui \& Sridhar, 2010). However, difficulties arise when preparation of micro electrodes of different metal is required. The use of microelectrodes to evaluate the corrosivity of a more resistive electrolyte as pure biodiesel has not been reported.

Electrochemical Impedance Spectroscopy (EIS) technique has been proposed to assess the corrosivity of the water-biodiesel system (Kamiński \& Kurzydłowski, 2008; Díaz-Ballote, López-Sansores, MaldonadoLópez \& Garfias-Mesias, 2009); but the effectiveness of the EIS technique used for direct evaluation of the corrosion of metals exposed to biodiesel is still under discussion. Due to the high resistivity of the fuel, the electrochemical measurements are difficult and it is not obvious to associate the response of such measurements to corrosion processes at the metal-biodiesel interface. The use of two identical electrode cells having a large surface area may overcome the difficulty of impedance measurements in high resistive electrolyte as fuel ethanol, but measurements have to be restricted to the corrosion potential (De Souza, Mattos, Sathler \& Takenouti, 1987). The experimental arrangement of two identical electrode cell to perform EIS measurements in order to evaluate the corrosion of metals in ethanolgasoline blends (Baena, Gómez \& Calderón, 2012) and ethanol-gasoline with water as contaminant (Jafari et al., 2011) have been conducted successfully.

This paper presents a systematic study addressed to evaluate the corrosivity of biodiesel and biodiesel-fatty acid blends during long exposure time. Metals commonly used in auto-parts and fuel storage structures such as copper, stainless steel, carbon steel, aluminum and tin were exposed to pure biodiesel and blends at different exposure conditions. After exposure, mass loss of the specimens was measured in order to 
evaluate the corrosion rates of the metals. Additionally, electrochemical measurements were performed using a 40-day immersion -using EIS- of the specimens in the test fuels. Thus, this technique was explored as a promising tool for assessing the corrosiveness of biodiesel and for monitoring the degradation of biodiesel. A cell configuration of two identical electrodes was used to overcome difficulties due to solution resistivity and to provide more reliable impedance measurements and facilitate the interpretation of results.

\section{EXPERIMENTAL METHODOLOGY}

Metallic samples of carbon steel (CS), 304 stainless steel (SS), aluminum (Al), tin ( $\mathrm{Sn})$ and copper $(\mathrm{Cu})$, were exposed to palm biodiesel in 3 different conditions: total immersion, partial immersion and vapor. The tests were conducted at temperatures of 25 and $45^{\circ} \mathrm{C}$. The sample area was $10 \mathrm{~cm}^{2}$, except for tin samples which were $8 \mathrm{~cm}^{2}$. Before the exposure, samples were manually polished with sandpaper 600 grit. Then, they were washed and degreased in water and ethanol. The fuel used for the immersion tests was pure palm biodiesel. Corrosion rates of metals were determined after samples exposition in the fuel by mass loss measurements, after 3, 6 and 12 months of exposition. All measurements were made in triplicate, and the results showed in this work are the average of the responses. Electrochemical measurements at different immersion times were performed using EIS technique of the metal samples immersed in biodiesel and biodiesel-fatty acids blends. The amount of fatty acid added in the mixture was $0.32 \mathrm{wt} \%$. The fatty acids added to biodiesel were those commonly found in important proportion in palm biodiesel, such as oleic acid, acetic acid, myristic acid, palmitic acid and stearic acid. The EIS tests were performed at room temperature in an electrochemical cell of two identical working electrodes, with $1 \mathrm{~mm}$ spacing between the electrodes. Details of the electrochemical cell are presented in Figure 1. The electrode area was 4 $\mathrm{cm}^{2}$. Several EIS measurements were performed to the metal samples during the immersion period, which was between 1 and 40 days, to follow the evolution of the corrosion parameters. The palm biodiesel and blends were therefore used as electrolytes. EIS measurements were carried out at OCP in a frequency range of $100 \mathrm{kHz}$ to $0.5 \mathrm{mHz}$ with sinusoidal perturbation amplitude of $50 \mathrm{mV}$. Other perturbation amplitudes were tested as 10 and $100 \mathrm{mV}$, but not significant differences between measurements were evidenced.

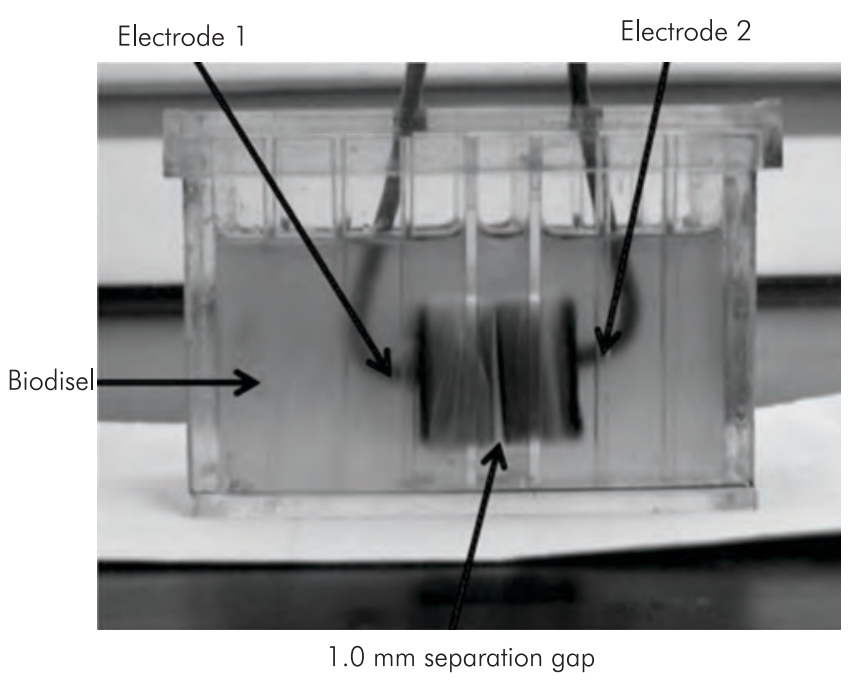

Figure 1. Electrochemical cell used in the EIS measurements.

\section{RESULTS AND DISCUSSION}

\section{Corrosion Rates of the Metals Exposed to Pure Palm Biodiesel}

The corrosion rates obtained by mass loss measurements of metals exposed by 1 year to pure palm biodiesel are presented in Table 1 . The temperature and exposure conditions (vapor, partial immersion, total immersion) did not have a significant effect on the corrosion of the SS samples. However, it is worth noting that the corrosion rate of SS tended to decrease during the exposure time, which is consistent with the existence of passivation process on the metal. The corrosion rates of the CS samples were between 0.2 and $1.0 \mu \mathrm{m} \cdot$ year $^{-1}$ and the response to different exposure conditions was similar to that observed in SS samples. The corrosion rate of aluminum samples were between 0.1 and $0.7 \mu \mathrm{m} \cdot$ year $^{-1}$. There was no influence of the temperature on the corrosion of aluminum, although there were slightly lower corrosion rates under partial immersion conditions. The corrosion of the aluminum tends to fall during the time of exposure in all exposure conditions. The corrosion rates of tin samples were between 0.2 and $1.5 \mu \mathrm{m}$.year ${ }^{-1}$. The 
corrosion behavior of tin was similar to that described for the aluminum. Copper was the metal that exhibited highest corrosion rate. Corrosion rates of copper at $25^{\circ} \mathrm{C}$ were between 1.0 and $5.0 \mu \mathrm{m} \cdot \mathrm{year}^{-1}$ and 1.0 and $160 \mu \mathrm{m} \cdot$ year $^{-1}$ for exposition at $45^{\circ} \mathrm{C}$. Unlike the other metals, copper exhibited the highest corrosion rates in total immersion conditions, followed by the corrosion rates on partial immersion. The copper corrosion rate increased during the first 6 months of exposition and then decreased. The corrosion rates obtained for all evaluated metals were between the ranges of values commonly reported in the literature for long exposure conditions in biodiesel (Kaul et al., 2007).

Because oleic, linoleic and palmitic acids are the major components of oxidized palm biodiesel, similarly to the exposition at pure biodiesel, metallic specimens were also exposed to mixtures of biodiesel and additions of $0.32 \%$ of the fatty acids in all exposure conditions. The mass loss results showed no significant differences between the corrosion rates of metals exposed to pure biodiesel and to biodiesel-fatty acids blends.

\section{Assessment of Susceptibility to Corrosion of Metals Immersed in Biodiesel by EIS}

Figure 2 shows the Nyquist impedance plots of different metals immersed for 15 days in biodiesel. It can be observed that these diagrams are constituted by a single capacitive loop. The impedance response of the electrochemical system could be the same of the impedance response of the electric circuit constituted by a resistor in parallel with a capacitor, schematically represented in Figure 3a. The values of the polarization resistance, which can be read at the limit of zero frequency, are on the order of $10^{9} \mathrm{ohm}$. $\mathrm{cm}^{2}$ and the associated capacitances of these loops are of the order of $10^{-11} \mathrm{~F} \cdot \mathrm{cm}^{-2}$ for all metals. According to those results, the capacitance $\left(\mathrm{C}_{\mathrm{b}}\right)$ and resistance $\left(\mathrm{R}_{\mathrm{b}}\right)$ extracted from impedance diagrams may neither be associated to the capacitance of the electric double layer nor to the charge transfer resistance of the metals immersed in biodiesel, because the capacitance values are too low and resistance values are too high as to be related to the electrochemical parameters of the metalbiodiesel interface. The impedance response observed in the experiments can be rather associated to the dielectric response biodiesel. On the other hand, there is evidence of decreasing of real impedance values during the exposure time. This could be associated with the increase of biodiesel conductivity resulting from release of metal ions due to corrosion of metal or polar compounds formation during the oxidation reactions of biodiesel. Thus, EIS measures could be used as a promising tool for continuous monitoring of the quality of biodiesel.

The results of EIS measurements of metals immersed in biodiesel-fatty acids blends (not presented in this paper) showed that the SS, Al and Sn behaved similarly to the immersion in pure biodiesel, showing a single capacitive loop in all evaluation times. Likewise, the impedance response would be associated only to changes in the conductivity of the biodiesel blends. Moreover, impedance measurements of copper and carbon steel immersed in biodiesel-fatty acid blends showed different behavior compared to those observed in pure biodiesel.

Figure 4 shows the impedance diagrams copper and carbon steel immersed for 960 hours (40 days) in biodiesel-fatty acid blends with $0.32 \%$ acetic acid and $0.32 \%$ linoleic acid. At the beginning of the exposure, it was observed that the CS and Cu samples behaved similarly to those seen in pure biodiesel immersion, showing a single capacitive loop in both biodiesel blends. However, after the second day of exposition, a second capacitive loop appeared at low frequencies. The capacitive loop at low frequencies is fully evident after 192 hours immersion ( 8 days). It is important to highlight that the impedance of copper

Table 1. Corrosion rates of metal exposed to biodiesel.

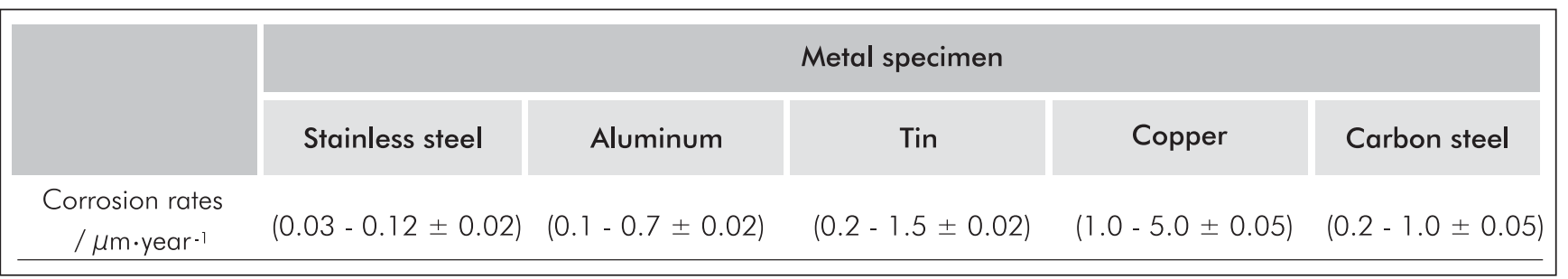




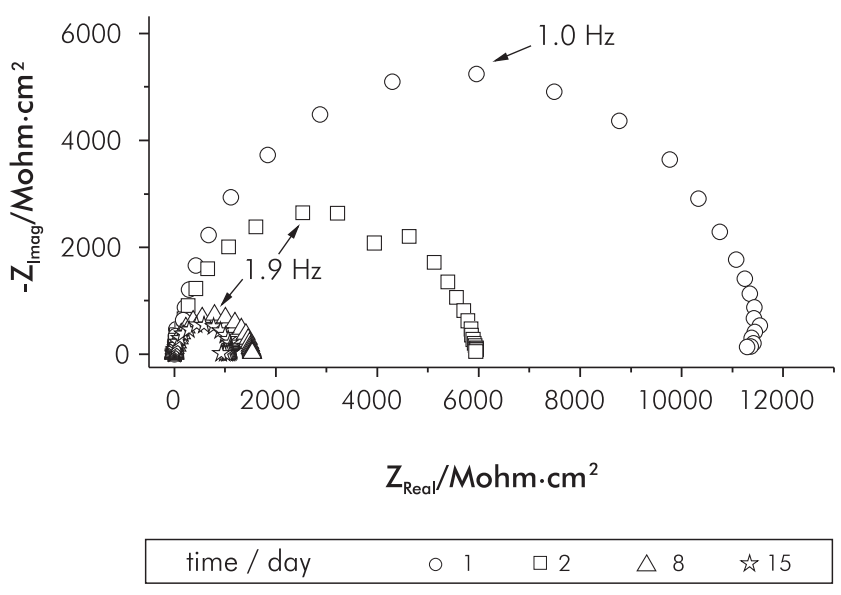

(a)

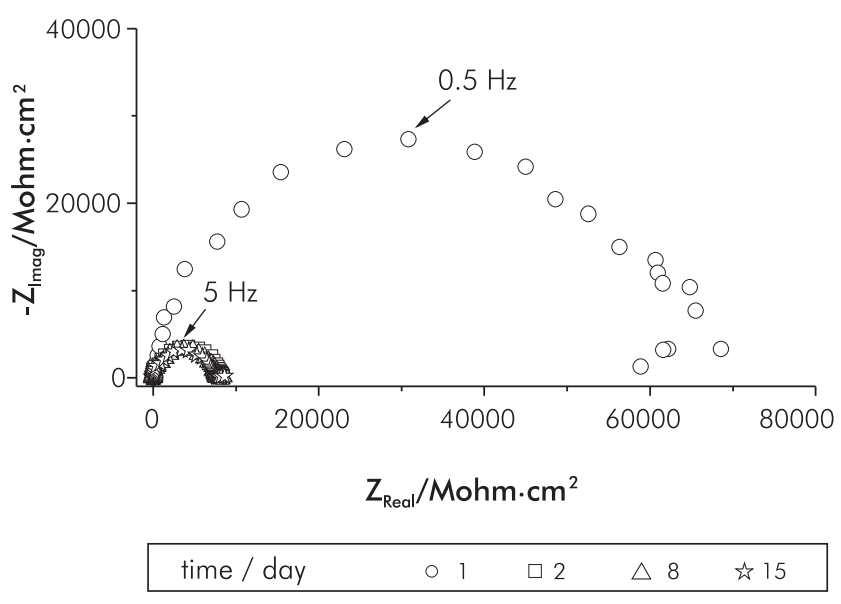

(c)

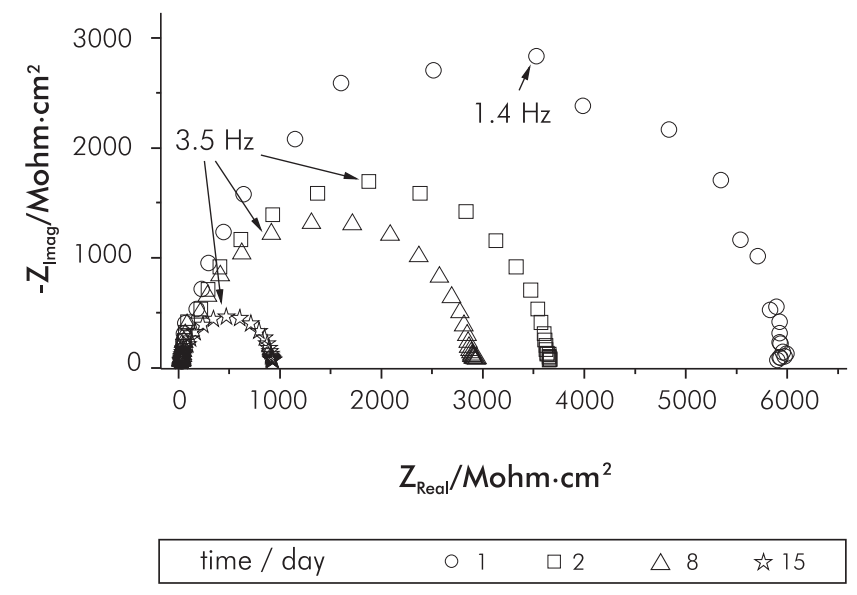

(b)

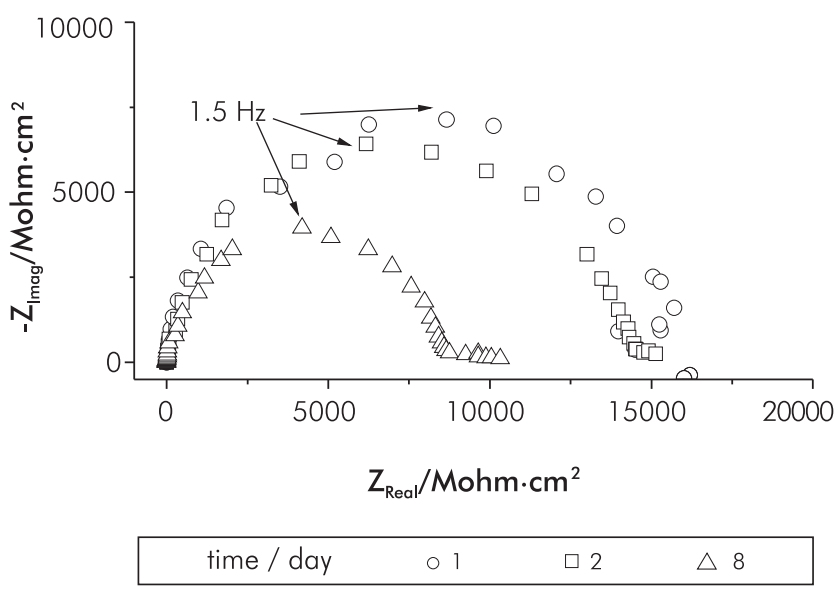

(d)

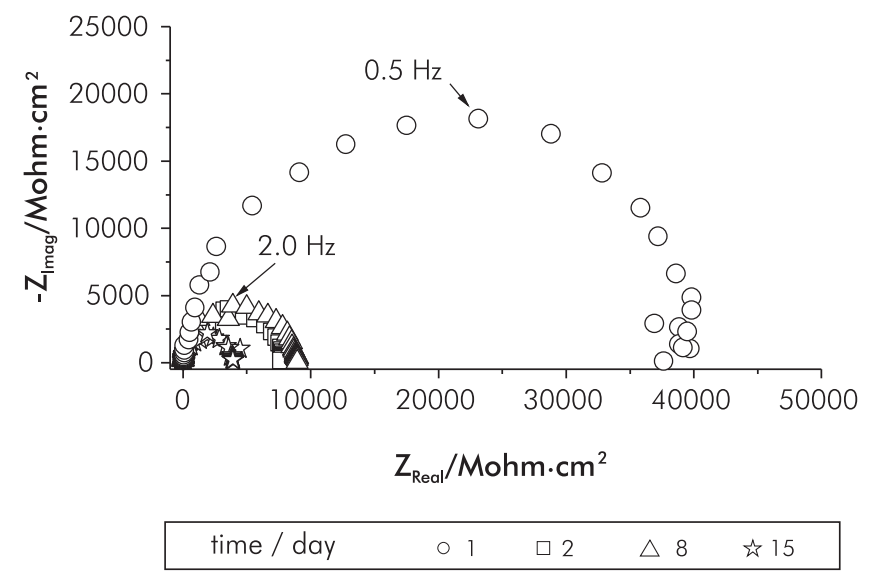

(e)

Figure 2. Nyquist impedance plots of metals at different immersion times in pure biodiesel. (a) stainless steel (SS), (b) aluminum (Al), (c) tin (Sn), (d) carbon steel (CS), (e) copper (Cu). 


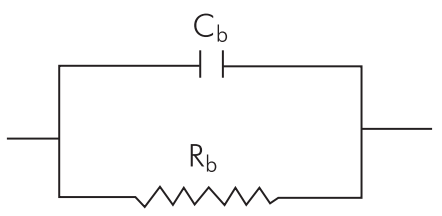

(a)

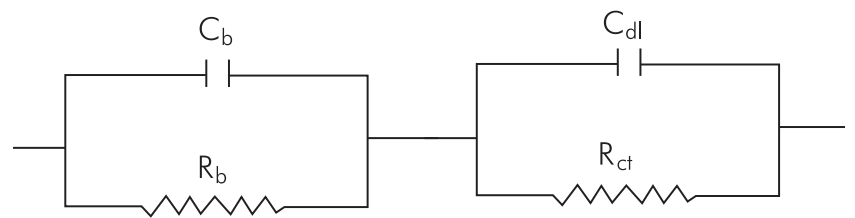

(b)

Figure 3. Equivalent electrical circuit for the impedance response. (a) pure biodiesel, (b) biodiesel-fatty acid blends for Cu and CS.

immersed in biodiesel-fatty acid blends showed higher separation of the two capacitive loops than the capacitive loops of carbon steel samples. This may be related to higher copper dissolution in these media, as was confirmed through measurements of mass loss and corrosion rates. Similarly to that observed during corrosion of copper and carbon steel in ethanol (Baena et al., 2012), the second capacitive loop at low frequencies may be related to the corrosion process of the metal, while the first capacitive loop at high frequencies can be directly related to changes in the dielectric properties of biodiesel by its interaction with metals.

The impedance response of the electrochemical system for copper and carbon steel after $48 \mathrm{~h}$ of immersion in biodiesel-fatty acid blends could be the same of the impedance response of the electric circuit constituted by two parallel RC circuits linked in series, schematically represented in Figure $3 b$. The electrical parameters of both metal extracted from the electrochemical impedance results are presented in Table 2.

The resistance of the biodiesel-fatty acid blends $\left(R_{b}\right)$ and the charge transfer resistance $\left(R_{c t}\right)$ of the metals can be extracted from EIS results, taking into account the real part of the impedance of the first loop at intermediate frequencies and the second loop at lowest frequencies, respectively. The resistance of the biodiesel blend with acetic acid decreased from 14 to $2 \mathrm{Gohm} \cdot \mathrm{cm}^{2}$ after 960 hours of testing, whereas linoleic acid mixture decreased from 40 to 8 Gohm. $\mathrm{cm}^{2}$. The charge transfer resistances $\left(\mathrm{R}_{\mathrm{ct}}\right)$ of $\mathrm{Cu}$ and $\mathrm{CS}$ samples immersed in biodiesel-acetic acid blends were close to 2.0 and $1.0 \mathrm{Gohm} \cdot \mathrm{cm}^{2}$, respectively; while the values of this parameter in the blend with linoleic acid were about 10 and $2.0 \mathrm{Gohm} \cdot \mathrm{cm}^{2}$ for the same metals. This indicates that the blend of biodiesel with $0.32 \%$ acetic acid was more corrosive than the linoleic acid blend. Additionally, the lower values of $\mathrm{R}_{\mathrm{ct}}$ exhibited by the CS samples in both biodiesel blends in comparison with those observed for $\mathrm{Cu}$ contradicts the expected result, since higher corrosion rates were observed for $\mathrm{Cu}$ samples exposed to pure biodiesel and biodiesel acid blends. As it has been proposed in others works (Fazal et al., 2010), copper is more susceptible to corrosion when immersed in biodiesel, and has the strongest detri mental and catalytic effect on biodiesel oxidation (Fazal, Haseeb \& Masjuki, 2013; Sarin et al., 2009). Moreover, the exhibition of the second capacitive loop and its evolution with time of exposition is more evident in copper samples than in carbon steel samples. The increasing of this loop follows concomitantly the increment of the exposition time -only in the copper samples-. This indicates that for copper samples, the second capacitive loop could be related with the metal-electrolyte-interface, while for carbon steel samples this loop could be related with inhomogeneities of the surface by biodiesel coverage on metal.

Although the capacitance values of the capacitive loop at low frequency $\left(\mathrm{C}_{\mathrm{dll}}\right)$ are still small $\left(10^{-9} \mathrm{~F} \cdot \mathrm{cm}^{-2}\right)$ as to be directly related to the capacitance of the electrical double layer, those values gradually increase with the immersion time, reaching in some cases values of $\mu \mathrm{F}$, indicating a direct relationship between the second capacitive loop with the corrosion phenomena at the metal-biodiesel interface for copper.

The relationship between the second capacitive loop in the impedance measurements at carbon steel with inhomogeneities of the surface by partial biodiesel coverage on metal, is based on the little evidence of this loop and its low evolution on the exposition time. A distortion of the overall impedance at low frequencies seems a better option. The distortion on the overall impedance at low frequencies could be caused by the extremely low current densities generated during 

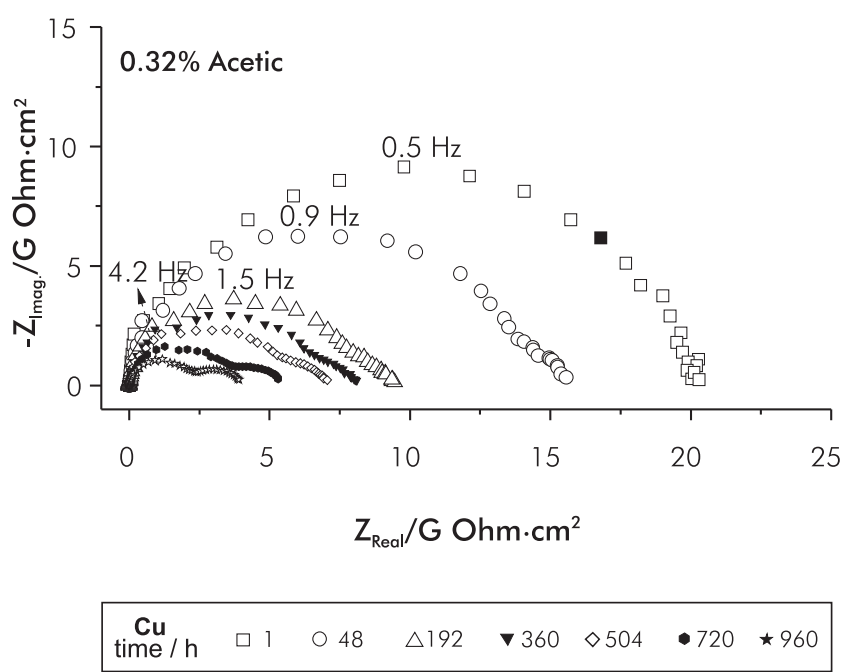

(a)

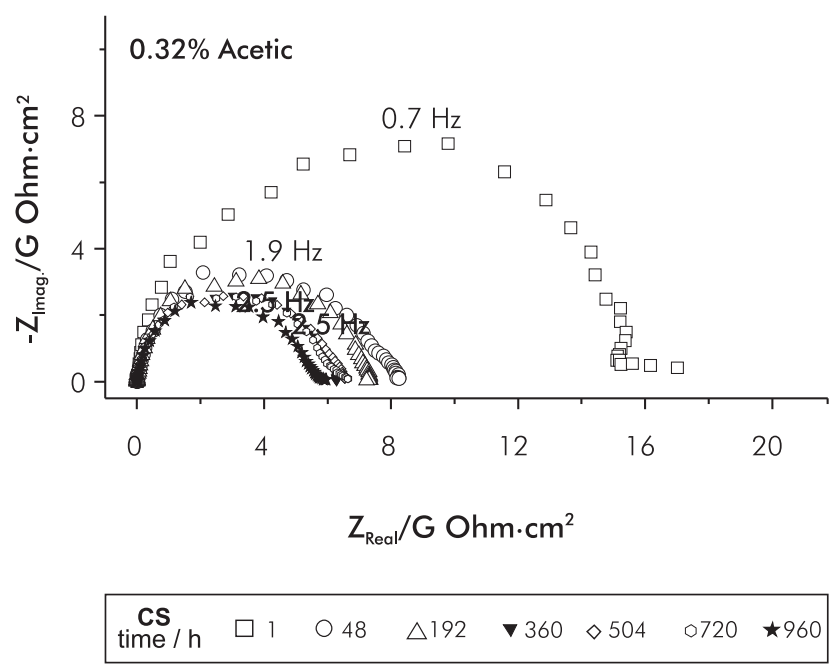

(c)

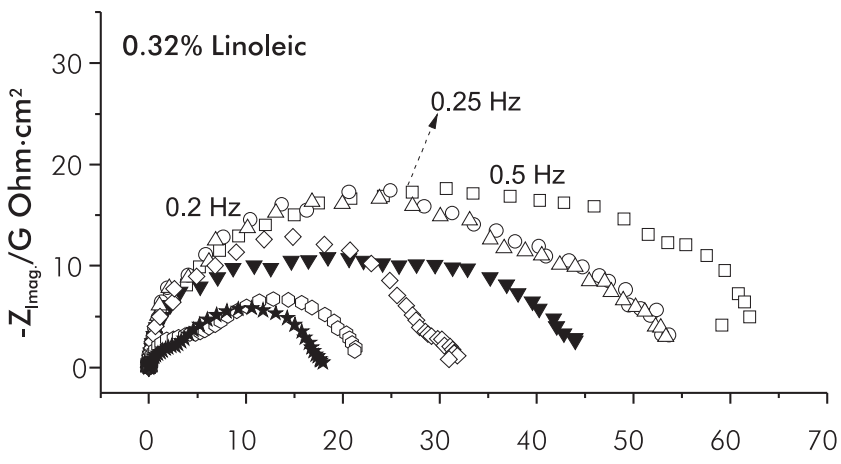

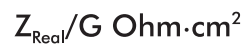

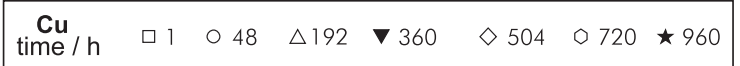

(b)

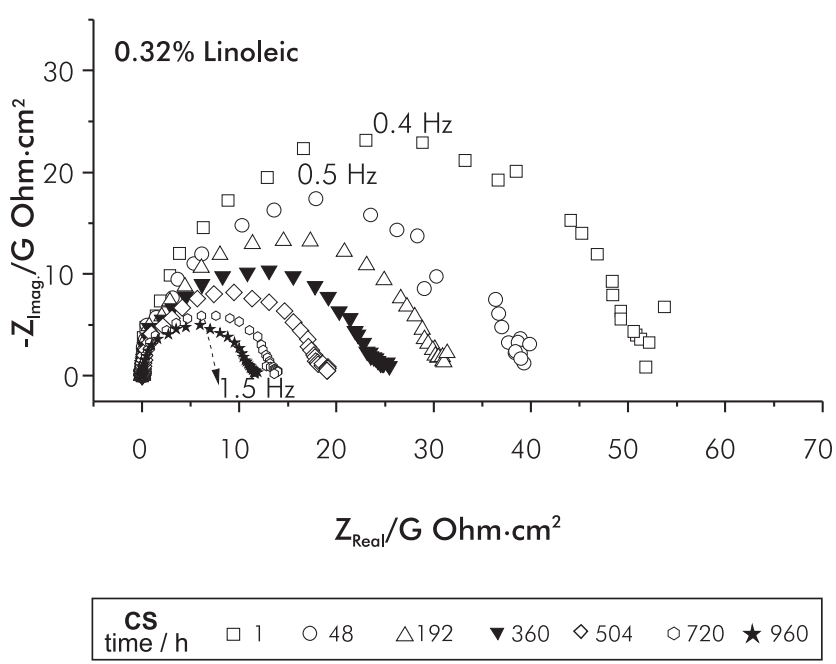

(d)

Figure 4. Nyquist impedance plots for copper (Cu) and carbon steel (CS) at different immersion times in biodiesel blends with $0.32 \%$ acetic acid and 0.32\% linoleic acid. (a) copper in acetic acid, (b) copper in linoleic acid, (c) carbon steel in acetic acid, (d) carbon steel in linoleic acid.

the corrosion process of carbon steel. Evidence of this phenomenon has been reported by Wang, Jenkins and Ren (2012). They found that when carbon steel samples are immersed in biodiesel-water mixtures, while all the anodes are located in the water phase due to low dissolved oxygen exposure, most cathodes were formed in the water phase along the water/ biodiesel interface. Relatively low corrosion current $\left(\mathrm{nA} \cdot \mathrm{cm}^{-2}\right)$ were detected in the biodiesel phase along the interface. This means that the metal immersed in biodiesel behaves entirely as a cathode, and very little corrosion on biodiesel phase is observed. 
Table 2. Electrical parameters of copper and carbon steel extracted from the electrochemical impedance results.

\begin{tabular}{|c|c|c|c|c|c|c|c|c|c|c|c|c|c|}
\hline \multirow{3}{*}{ Metal } & \multirow{3}{*}{ Parameter } & \multicolumn{6}{|c|}{ Biodiesel $+0.32 \%$ acetic acid } & \multicolumn{6}{|c|}{ Biodiesel $+0.32 \%$ linoleic acid } \\
\hline & & \multicolumn{6}{|c|}{ Time / h } & \multicolumn{6}{|c|}{ Time / h } \\
\hline & & 48 & 192 & 360 & 504 & 720 & 960 & 48 & 192 & 360 & 504 & 720 & 960 \\
\hline \multirow{4}{*}{ Cu } & $\mathrm{R}_{\mathrm{b}} / \mathrm{Gohm} \cdot \mathrm{cm}^{2}$ & 14 & 7.5 & 6.5 & 5.2 & 3.0 & 2.2 & 40 & 38 & 25 & 22 & 10 & 8 \\
\hline & $\mathrm{C}_{\mathrm{b}} / \mathrm{pF} \cdot \mathrm{cm}^{-2}$ & 85 & 89 & 100 & 130 & 80 & 100 & 50 & 52 & 80 & 90 & 200 & 250 \\
\hline & $\mathrm{R}_{\mathrm{ct}} / \mathrm{Gohm} \cdot \mathrm{cm}^{2}$ & 2.6 & 2.0 & 1.8 & 1.8 & 1.6 & 1.6 & 13 & 15 & 17 & 9 & 10 & 9 \\
\hline & $\mathrm{C}_{\mathrm{dl}} / \mathrm{nF} \cdot \mathrm{cm}^{-2}$ & 9.6 & 12.5 & 13.9 & 13.9 & 15.6 & 15.6 & 1.5 & 1.3 & 1.2 & 2.2 & 2.0 & 2.2 \\
\hline \multirow{4}{*}{ CS } & $\mathrm{R}_{\mathrm{b}} / \mathrm{Gohm} \cdot \mathrm{cm}^{2}$ & 7.5 & 6.8 & 6.2 & 6.0 & 5.7 & 5.1 & 37 & 28 & 22 & 17 & 12.3 & 10 \\
\hline & $\mathrm{C}_{\mathrm{b}} / \mathrm{pF} \cdot \mathrm{cm}^{-2}$ & 55 & 61 & 67 & 69 & 73 & 82 & 30 & 40 & 52 & 67 & 92 & 113 \\
\hline & $R_{c t} /$ Gohm $\cdot \mathrm{cm}^{2}$ & 0.7 & 0.55 & 0.1 & 0.5 & 0.9 & 0.8 & 3.0 & 3.0 & 2.6 & 2.0 & 1.6 & 1.1 \\
\hline & $\mathrm{C}_{\mathrm{d} \mid} / \mathrm{nF} \cdot \mathrm{cm}^{-2}$ & 28.6 & 36.4 & 200 & 40 & 22 & 25 & 14 & 14 & 16 & 20 & 26 & 38 \\
\hline
\end{tabular}

\section{CONCLUSIONS}

- During the immersion in biodiesel and biodiesel-fatty acid blends, copper showed the highest corrosion rates, particularly in the condition of total immersion which was in the order of 1.0 and $5.0 \mu \mathrm{m} \cdot$ year $^{-1}$, and 1.0 and $160 \mu \mathrm{m} \cdot$ year ${ }^{-1}$ for exposition at $45^{\circ} \mathrm{C}$.

- Corrosion rates for all metals tested, except for copper, tended to decrease with the exposure time, which could indicate passivation of metal surface in biodiesel and in biodiesel-acids blends.

- The electrochemical impedance responses observed in the immersion tests for stainless steel, aluminum and tin are associated mainly with the changes in the dielectric parameters of biodiesel. This means that corrosion phenomena cannot be directly associated to the electrochemical parameters obtained by electrochemical impedance measurements, under the current experimental conditions. However, a decrease of the biodiesel resistance values was observed during the exposure time. This result could be related to the increasing of conductivity of biodiesel, possibly due to releasing of metal ions into the fuel.

- The corrosion phenomena of the metals immersed in biodiesel and biodiesel-fatty acid blends were detected by the electrochemical impedance technique for copper and carbon steel samples after $48 \mathrm{~h}$ of immersion in the biodiesel-fatty acid blends. In that condition, only copper samples showed a second capacitive loop at lower frequencies that increases concomitantly with increasing of the exposition time, which could be associated to the metal corrosion. The charge transfer resistance exhibited by copper in biodiesel- $0.32 \%$ acetic acid blend was lower than that observed in biodiesel- $0.32 \%$ linoleic acid, been 1.6 and $9.0 \mathrm{Gohm} \cdot \mathrm{cm}^{2}$, respectively. This indicates a major corrosiveness of the biodiesel-acetic acid mixture. 


\section{ACKNOWLEDGEMENTS}

The authors wish to thank Colciencias (1115-48925421 project - contract 630-2009) and the Universidad de Antioquia ("Proyecto de sostenibilidad 2013 to 2014") for the support received during this project.

\section{REFERENCES}

Aquino, I. P., Hernández, R. P. B., Chicoma, D. L., Pinto, H. P. F. \& Aoki, I. V. (2012). Influence of light, temperature and metallic ions on biodiesel degradation and corrosiveness to copper and brass. Fuel, 102: 795-807.

Baena, L. M., Gómez, M. \& Calderón, J. A. (2012). Aggressiveness of a $20 \%$ bioethanol- $80 \%$ gasoline mixture on autoparts: I behavior of metallic materials and evaluation of their electrochemical properties Fuel, 95: 320-328.

Brossia, C., Gileadi, E. \& Kelly, R. (1995). The electrochemistry of iron in methanolic solutions and its relation to corrosion. Corros. Sci., 37(9), 1455-1471.

De Souza, J. P., Mattos, O. R., Sathler, L. \& Takenouti, H. (1987). Impedance measurements of corroding mild steel in an automotive fuel ethanol with and without inhibitor in a two and three electrode cell. Corros. Sci., 27(12), 1351-1364.

Díaz-Ballote, L., López-Sansores, J., Maldonado-López, L. \& Garfias-Mesias, L. J. (2009). Corrosion behavior of aluminum exposed to a biodiesel. Electrochem. Commun., 11(1), 41-44.

Fazal, M. A., Haseeb, A. S. M. A. \& Masjuki H. H. (2010). Comparative corrosive characteristics of petroleum diesel and palm biodiesel for automotive materials. Fuel Process. Technol., 91(10), 1308-1315.

Fazal, M. A., Haseeb, A. S. M. A. \& Masjuki H. H. (2013). Corrosion mechanism of copper in palm biodiesel. Corros. Sci., 67: 50-59.

Gui, F. \& Sridhar, N. (2010). Conducting electrochemical measurements in fuel-grade ethanol using microelectrodes. Corrosion, 66(4), 045005-1-045005-8.

Gui, F., Sridhar, N. \& Beavers, J. (2010). Localized corrosion of carbon steel and its implications on the mechanism and inhibition of stress corrosion cracking in fuel-grade ethanol. Corrosion, 66(12), 125001-1-125001-12.
Haseeb, A. S. M. A., Masjuki, H. H., Ann, L. J. \& Fazal., M. A. (2010). Corrosion characteristics of copper and leaded bronze in palm biodiesel. Fuel Process. Technol., 91(3), 329-334.

Jafari, H., Idris, M., Ourdjini, A., Rahimi, H. \& Ghobadian, B. (2011). EIS study of corrosion behavior of metallic materials in ethanol blended gasoline containing water as a contaminant. Fuel, 90(3), 1181-1187.

Kamiński, J. \& Kurzydłowski, K. J. (2008). Use of impedance spectroscopy to testing corrosion resistance of carbon steel and stainless steel in water-biodiesel configuration. J. Corros. Meas. (JCM), 6: B35-B39.

Kaul, S., Saxena, R. C., Kumar, A., Negi, M. S., Bhatnagar, A. K., Goyal, H. B. \& Gupta, A. K. (2007). Corrosion behavior of biodiesel from seed oils of Indian origin on diesel engine parts. Fuel Process. Technol., 88(3), 303-307.

Lou, X., Yang, D. \& Singha, P. M. (2010). Film breakdown and anodic dissolution during stress corrosion cracking of carbon steel in bioethanol. J. Electrochem. Soc., 157(2), C86-C94.

Niczke, L., Czechowski, F. \& Gawel, I. (2007). Oxidized rapeseed oil methyl ester as a bitumen flux: Structural changes in the ester during catalytic oxidation. Prog. Org. Coat., 59(4), 304-311.

Sarin, A., Arora, R., Singh, N. P., Sharma, M. \& Malhotra, R. K. (2009). Influence of metal contaminants on oxidation stability of Jatropha biodiesel. Energy, 34(9), 1271-1275.

Sridhar, N., Price, K., Buckingham, J. \& Dante, J. (2006). Stress corrosion cracking of carbon steel in ethanol. Corrosion, 62(8), 687-702.

Wang, W., Jenkins, P. E. \& Ren, Z. J. (2012). Electrochemical corrosion of carbon steel exposed to biodiesel/simulated seawater mixture. Corros. Sci., 57: 215-219.

\section{AUTHORS}

\section{Jorge A. Calderón}

Affiliation: Universidad de Antioquia

Metallurgical Engineer, Universidad de Antioquia

M. Sc. in Chemistry Science, Universidad de Antioquia

$\mathrm{Ph}$. D. in Metallurgical and Materials Engineering,

Universidade Federal de Rio de Janeiro

Post Ph. D. in Metallurgical and Materials Engineering,

Universidade Federal de Rio de Janeiro

e-mail: jcaldergut@gmail.com 


\section{Libia María Baena}

Affiliation: Universidad de Antioquia

Materials Engineer, Universidad de Antioquia

M. Sc. in Engineer, Universidad de Antioquia

$\mathrm{Ph}$. D. Student in Materials Engineer,

Universidad de Antioquia

e-mail: libiaudea@gmail.com

\section{Julian Lenis}

Affiliation: Universidad de Antioquia

Materials Engineer Student, Universidad de Antioquia

e-mail: julian_aes@hotmail.com 
